\title{
Inventory of Associated Marine Macro Algae Species to Rissoides Desmaresti (Crustacea - Stomatopoda), with screening of Bioactivity of shell extract Amr M. Nasef \\ Marine Biology Section, Zoology Department, Faculty of Science, Al-Azhar University, Nasr City - Cairo - Egypt. \\ Email: marine@azhar.edu.eg, Mobile:00201009324339
}

\begin{abstract}
Background: Shrimp, Rissoides desmaresti, making a healthy choice for human consumption.

Objective: This study aimed to isolate, and identify some natural bioactive marine products from its shell extract, as well as to investigate the biological activity of the seashell extract and the degree of its influence on various microbiological species and laryngeal cancer,, as well as to discover the distribution and relationship between it and marine algae, as the marine food chain. Materials and methods: Squills were gathered, and the varieties of marine algae connected with the organism in the maritime environment were tallied, since they are a major contributor in the marine environment's productivity. Several biologically active marine natural components were extracted, separated, and identified from the organism under research. Results: The findings revealed a seasonal variation in the percentage of marine algae present, which was reflected on diversity in the environment from one season to the next, and indicated the magnitude of the effect of seasonal change on productivity, food availability, and environmental yield. Antimicrobial activity of Rissoides desmaresti shell extract revealed significant differences between groups treated with shell extract $(1.5,2.5$, and $5 \mathrm{mg} / \mathrm{mL})$ in comparison with the control group. In addition, the viability of the Hep -2 cell line after treatment with Rissoides desmaresti shell extract was assessed and microscopic examination revealed a significant difference between the shell extract-treated groups and the control group. Depending on the dosage or concentration, cell viability decreased in a dose dependent way. The shell extract suppressed the growth of cancer cell line of larynx. Conclusion: The current study revealed that there was seasonal variation in the percentage of marine algae present, which is reflected in the observed species numbers of marine macro algae in the environment of the organism under study and had an impact on marine productivity, food availability, and eco-physiology of Rissoides desmaresti. Shell extract can be employed as an antibacterial, antifungal, and anticancer agent because of several natural bioactive marine compounds from Rissoides desmaresti shell extract.
\end{abstract}

Keywords: Mediterranean sea, Rissoides desmaresti, Benthos, Marine, Macro algae.

\section{INTRODUCTION}

Although the effect of seasonal changes on the environment and marine organisms has been previously studied in several articles, the field is still large and needs more innovative studies, and from different angles, especially after the emergence of the phenomenon of climate change. Whiteley ${ }^{(1)}$ studied physiological and ecological responses of crustaceans and stated that the species most at risk are exclusively marine that have limited physiological capacities to adjust to environmental changes. These changes could affect species survival, distribution and abundance. Numerous interconnected environmental variables are expected to have an impact on community makeup and organisation. Ecological variables have influenced the physiology and distribution of marine creatures through physical and chemical stress, according to Davenport et al. ${ }^{(2,3)}$. The consequences of climate change, particularly ocean warming and acidification are fast-growing and rapidly changing fields of inquiry.

The photosynthetic activity of aquatic flora, temperature, salinity, and the quantity of organic components all have a significant impact ${ }^{(4,5)}$. The findings of Velasco et al. ${ }^{(\boldsymbol{(})}$ showed that abiotic stressors such as (temperature, pH...etc.) have an impact on marine creatures (fauna or flora) in several physiological aspects that define the performance and composition of the aquatic organism. Understanding and anticipating the impacts of numerous stressors in the face of global change is one of the most important concerns in conservation and applied ecology $(7,8)$.

Various compounds can be present in the environment and organisms; the occurrence of these chemicals is influenced not only by species, but also by environmental and seasonal conditions. According to Trung and Phuong ${ }^{(9)}$, shrimp (Penaeus monodon) heads can be an excellent source of bioactive chemicals. Abouzeed et al. ${ }^{(10)}$ looked on the synthesis and physicochemical features of several beneficial substances derived from squilla (Oratosquilla massavensis) shells. Benedetta and Paul (11) stated that we are in need for scientific information about mantis shrimp (Squilla mantis), to improve the state of marine ecosystems.

Anticancer chemicals, antibiotics, and enzyme inhibitors have all been found in marine natural products. Despite the present interest in bioactive marine chemicals, our understanding is restricted due to the field's recent history ${ }^{(12)}$. Crustaceans and marine algae play a significant part in the ecosystem's evaluation and production. It is well recognised that it 
plays an essential role in the food web, productivity, and the overall marine ecology. So that recently, the search for crustaceans and marine algae has grown increasingly crucial in all ecosystems. Because of abundance of their bioactive chemicals, marine macro algae are one of nature's most biologically active resources. Antibacterial action, antioxidant ability, anti-inflammatory characteristics, anticoagulant activity and antiviral activity, have all been reported in isolated chemicals from marine macro-algae ${ }^{(13,14)}$.

As a result, the current study was created to accomplish the following objectives:

To learn more about the ecological interaction between marine algae and Squilla mantis (Stomatopoda Squillidae), researchers conducted the following: Studying the distribution, prevalence, and statistical analysis, with an experiment to clarify the applied and medical importance by extraction, isolation, and identification of some bioactive marine natural products and screening of crude extracts for bioactivity to determine its effects on bacteria, fungi and Larynx cancer (Hep II cell line).

\section{MATERIALS AND METHODS Sampling:}

Seasonal sampling for Rissoides desmaresti was conducted out for this study during a one-year period, from January 2015 to January 2016, along the Southwestern coast of al max Bay,Mediterranean sea ( Alexandriah Governorate). Specimens labelled as XL when collected on the beach. Then, the obtained specimens were taken to laboratory for analysis.

\section{Species identification of benthic crustaceans:}

Fishing-related FAO species identification sheets were used for identification ${ }^{(15)}$.

\section{Identification of marine algae species:}

The research area's location revealed that the littoral parts of the shore are both sandy and muddy. Foreign particles, sand particles, and epiphytes were removed from the seaweed samples by hand and promptly rinsed with saltwater. The samples were then placed in an ice box and carried to the laboratory, where they were extensively cleaned with tap water to remove the salt on the surface. The samples were then identified according to species ${ }^{(16,17}$, and 18$)$.

\section{Bioactivity studies}

\section{1- Preparation of the volatile constituents:}

The volatile constituents were obtained by hydro distillation of the extract using the E.P apparatus. The distilled oil was extracted with ether after saturation with sodium chloride. Ether extract was dehydrated. Over anhydrous sodium sulphate, solvent was removed under reduced pressure at low temperature. Oil was kept in cold place in dark container tell analysis according to Masada ${ }^{(19)}$.

Identification of the constituents:
Qualitative identification of different constituents was done by TLCSilica gel using Benzene EtAc (93:7) for one dimentional TLC, and $\mathrm{CHCL}_{3} \mathrm{EtAc}$ (93:7) then Benzene: EtAc (93:7) for two dimentional TLC. Vaniline $\mathrm{H}_{2} \mathrm{SO}_{4} 1 \%$ was used as a spray Reagent. GC/MS was done using the apparatus GC/MS system.

2- Anti-microbial activity:

Most of the synthesized compounds were evaluated for their anti-microbial activity using the agar diffusion technique according to Cooper ${ }^{(20)}$.

\section{Microbial Organisms:}

Escherichia coli (NCTC10418): Gram -ve straight rods that occur in the lower part of the intestine.

Bacillus subtilis (NCIMB8054): Endospore-forming Gram +ve rods.

Klebsilla pneumonia: Gram -ve bacteria, straight rods and normal in habitants of the intestinal tract and cause the urinary and respiratory tract infection.

Pseudomonas aeruginosa: Gram -ve rods, often can cause respiratory and urinary tract infection.

Staphylococcus aureus (ATCC 29737): Gram +ve potential pathogen causing a wild range of infections e.g. pneumonia and various abscesses.

Bacillus pumilus: Gram positive bacteria, rods shape and endospore forming.

Micrococcus luteus: Gram positive bacteria, cocci primary habitat in mammalian skin.

Candidal albicans: Yeast -like microorganism pathogen causes Candidiasis.

Aspergillus niger: Multi-cellular fungi that cause disturbance in respiratory system and lung.

Aspergillus flavus: Multi-cellular fungi that cause disturbance in respiratory system and lung.

The inoculum prepared from a typical colony grown overnight on nutrient agar. Colony sampled less than 24 hours old transfer the growth to a tube of sterile saline.

\section{3- Anti-Cancer Activity: CELL CULTURE TECHNIQUES}

These methods carried according to Senthilraja and Kandasamy ${ }^{(21)}$ for making Subculture of a cell line: Hep II cell line (Larynx cancer).

Ethical approval: The study was approved by the Ethics Board of Al-Azhar University.

RESULTS

Seasonal variation of marine algae: 
The results showed a seasonal variation in the percentage of marine algae presence, which was reflected on the observed species numbers from one season to another in the environment of the organism under study. The number of marine algae was seasonally recorded during the period from January 2015 to January 2016, grouped by the major divisions: Rhodophyceae (red algae), Phaeophyceae (brown algae) and Ulvophyceae (green algae), In order to monitor the seasonal fluctuations at the percentage of presence.

\section{Rhodophyceae (red algae):}

In table (1), the observed species number differed from one season to another in the environment, where highest number was 25 recorded in spring, while the lowest was 15 recorded in winter. On the other hand the numbers of species were 21 and 17 in the summer and autumn respectively, with annual total for the number of species was (25) species.

\section{Phaeophyceae (brown algae):}

Table (2) showed species number of marine algae where the minimum number was 10 recorded during winter, but the maximum number of species was 17 recorded during spring, with annual total for species was 18, while summer and autumn seasons recorded 16 and 13 species respectively.

\section{Ulvophyceae (green alga)}

In table (3), the observed species number differed from one season to another in the environment where highest number was 18 recorded in spring, while the lowest was 13 recorded in winter. On the other hand, the numbers of species was 16 in the summer and autumn respectively, while annual total was 18 .

Table (1): Seasonal variation of Macro algae (Rhodophyta)

\begin{tabular}{|l|c|c|c|c|}
\hline Rhodophyta & Winter & Spring & Summer & Autumn \\
\hline Amphiroa rigida & + & + & + & - \\
\hline Ceramium ciliatum & - & + & + & + \\
\hline $\begin{array}{l}\text { Ceramium } \\
\text { diaphanum }\end{array}$ & + & + & - & + \\
\hline Ceramium virgatum & + & + & + & - \\
\hline Champia parvula & + & + & + & + \\
\hline Corallina officinalis & - & + & + & + \\
\hline Dasya hutchinsiae & - & + & + & + \\
\hline Ellisolandia elongata & + & + & - & - \\
\hline Gelidium crinale & + & + & + & + \\
\hline Gracilaria armata & - & + & + & + \\
\hline Gracilaria dura & + & + & + & - \\
\hline Halymenia elongata & - & + & + & + \\
\hline Halymenia floresii & - & + & + & - \\
\hline Jania adhaerens & + & + & + & + \\
\hline Jania rubens & + & + & + & + \\
\hline Laurencia obtuse & + & + & - & - \\
\hline Liagora viscida & + & + & + & + \\
\hline $\begin{array}{l}\text { Nemalion } \\
\text { elminthoides }\end{array}$ & + & + & + & + \\
\hline $\begin{array}{l}\text { Chondrophycus } \\
\text { papillosus }\end{array}$ & + & + & + & + \\
\hline Palisada thuyoides & - & + & + & + \\
\hline Polysiphonia opaca & - & + & - & - \\
\hline Pyropia leucosticta & + & + & + & - \\
\hline Rytiphlaea tinctoria & - & + & + & + \\
\hline Scinaia furcellata & + & + & + & + \\
\hline Spyridia filamentosa & - & + & + & + \\
\hline \multicolumn{1}{|c|}{ Seasonal total } & $\mathbf{1 5}$ & $\mathbf{2 5}$ & $\mathbf{2 1}$ & + \\
\hline \multicolumn{1}{|c|}{ Annual total } & & & + & + \\
\hline
\end{tabular}


Table (2): Seasonal variation of Macro algae (Phaeophyceae)

\begin{tabular}{|c|c|c|c|c|}
\hline Phaeophyceae & Winter & Spring & Summer & Autumn \\
\hline Colpomenia sinuosa & + & + & + & + \\
\hline Cystoseira compressa & - & + & + & - \\
\hline Cystoseira montagnei & + & + & + & + \\
\hline Dictyota dichotoma & - & + & + & + \\
\hline Dictyota fasciola & - & + & + & + \\
\hline Dictyota implexa & + & + & + & - \\
\hline Halopteris filicina & + & + & + & + \\
\hline Halopteris scoparia & - & + & + & - \\
\hline Myrionema conchicola & - & + & + & + \\
\hline Nereia filiformis & + & + & + & + \\
\hline Padina pavonica & + & + & + & + \\
\hline Petalonia fascia & + & + & - & + \\
\hline Punctaria latifolia & + & + & - & - \\
\hline Sargassum acinarium & + & + & + & + \\
\hline Scytosiphon lomentaria & - & - & + & - \\
\hline Sphacelaria cirrosa & - & + & + & + \\
\hline Stilophora tenella & - & + & + & + \\
\hline Taonia atomaria & + & + & + & + \\
\hline Seasonal total & 10 & 17 & 16 & 13 \\
\hline Annual total & \multicolumn{4}{|c|}{18} \\
\hline
\end{tabular}

Table (3): Seasonal variation of Macro algae (Ulvophyceae)

\begin{tabular}{|l|c|c|c|c|}
\hline Ulvophyceae & Winter & Spring & Summer & Autumn \\
\hline Bryopsis corymbosa & - & + & + & + \\
\hline Bryopsis hypnoides & + & + & + & + \\
\hline Chaetomorpha linum & + & + & + & + \\
\hline Cladophora gracilis & - & + & + & + \\
\hline C. lehmanniana & + & + & + & + \\
\hline Codium decorticatum & + & + & + & + \\
\hline Derbesia tenuissima & - & + & + & + \\
\hline Lychaete pellucida & + & + & + & + \\
\hline Ulva clathrata & + & + & + & + \\
\hline Ulva compressa & + & + & + & + \\
\hline Ulva flexuosa & + & + & + & + \\
\hline Ulva intestinalis & - & + & + & + \\
\hline Ulva lactuca & + & + & + & + \\
\hline Ulva linza & + & + & + & + \\
\hline Ulva rigida & + & + & + & + \\
\hline Ulvella setchellii & + & + & - & + \\
\hline Valonia macrophysa & - & + & + & - \\
\hline Valonia utricularis & + & + & - & - \\
\hline \multicolumn{1}{|c|}{ Seasonal total } & $\mathbf{1 3}$ & $\mathbf{1 8}$ & $\mathbf{1 6}$ & $\mathbf{1 6}$ \\
\hline & & & $\mathbf{1 8}$ & \\
\hline
\end{tabular}

\section{Bioactivity studies}

Preparation of the volatile constituents:

Biochemical compounds from G C-Mass spectrometry:

The chemical compound (by G C-Mass spectrometry analysis) of Rissoides desmaresti shell extract, which was extracted using hydro-distillation contained volatile compounds that were documented in tables (4) \& (5). 
Table (4): the chemical composition of Rissoides desmaresti shell extract:

\begin{tabular}{|c|c|c|c|c|c|}
\hline $\mathbf{N}$ & R. $\mathbf{T}$ & $\begin{array}{l}\text { Molecular } \\
\text { weight }\end{array}$ & $\begin{array}{l}\text { Base } \\
\text { Peak }\end{array}$ & Another Fragment & Compound Name \\
\hline 1- & 5.170 & 88 & 59 & $43-88-73$ & $\begin{array}{c}\text { Ethyle propyle ether } \\
\text { C5 H12 O }\end{array}$ \\
\hline $2-$ & 5.016 & 102 & 59 & $102-69-87-43$ & $\begin{array}{c}\text { 2- Butanone, 3-hydroxy- 3- } \\
\text { methyle } \\
\text { C5 H10 O2 }\end{array}$ \\
\hline 3- & 11.39 & 71 & 44 & $55-71$ & $\begin{array}{c}\text { 2- Propenamide } \\
\text { C3 H5 N O }\end{array}$ \\
\hline 4- & 11.391 & 72 & 44 & $72-55$ & $\begin{array}{l}\text { Cyclobutanol } \\
\text { C4 H8 O }\end{array}$ \\
\hline 5- & 24.42 & 206 & & 191 & $\begin{array}{l}\text { 2, } 4 \text {.Ditert butylephenol } \\
\text { C14 H22 O }\end{array}$ \\
\hline 6- & 27.667 & 156 & 43 & 155-141-111-105-207-85-71-57 & $\begin{array}{l}\text { Isooctyl vinyl ether } \\
\text { C } 10 \text { H20 O }\end{array}$ \\
\hline 7- & 27.667 & 184 & 43 & 155-141-127-113-99 -85 -71-57 & $\begin{array}{l}\text { Tridecane } \\
\text { C13 H28 }\end{array}$ \\
\hline 8- & 27.665 & 212 & 43 & $\begin{array}{c}\text { 183-169-155-141-127-113-99- } \\
212-85 \text { 71-57 } \\
\end{array}$ & $\begin{array}{c}\text { Pentadecane } \\
\text { C } 15 \mathrm{H32} \\
\end{array}$ \\
\hline 9. & 28.700 & 267 & 105 & 223-125-117-249-83-51-77 & $\begin{array}{c}\text { N-Bz- } 2 \text { Amino cinnamate } \\
\text { C } 17 \text { H17 NO2 }\end{array}$ \\
\hline 10- & 28.70 & 212 & 105 & 122-151-165-65-51-77-212-91 & $\begin{array}{l}\text { Benzyle ester of benzoic ACI } \\
\text { C } 14 \mathrm{H12} \mathrm{O2}\end{array}$ \\
\hline 11- & 29.2 & 310 & 43 & $\begin{array}{c}\text { 68-207-55-82-96-110-179-222- } \\
152-53-55-81-82-109\end{array}$ & $\begin{array}{c}\text { Heneicosane,3-methyle } \\
\text { (Docosane) } \\
\text { C22 H46 }\end{array}$ \\
\hline 12- & 31.310 & 280 & 43 & $\begin{array}{c}154-208-125-167-111-279-83- \\
97-149-69-57\end{array}$ & $\begin{array}{c}\text { Methyle [ N-(salicyl) -3- } \\
\text { amidepropanyl ]amino acetate } \\
\text { C13 H16 N2 O5 }\end{array}$ \\
\hline
\end{tabular}

Table (5): The chemical Compound of Rissoides desmaresti shell extract:

\begin{tabular}{|l|c|}
\hline 1 & Ethyle propyle ether C5 H12 O \\
\hline 2 & 2- Butanone, 3-hydroxy- 3- methyle C5 H10 O2 \\
\hline 3 & 2 - Propenamide C3 H5 N O \\
\hline 4 & Cyclobutanol C4 H8 O \\
\hline 5 & 2, 4 .Ditert butylephenol C14 H22 O \\
\hline 6 & Isooctyl vinyl ether C 10 H20 O \\
\hline 7 & Tridecane C13 H28 \\
\hline 8 & Pentadecane C 15 H32 \\
\hline 10 & N-Bz- 2 Amino cinnamate C 17 H17 NO2 \\
\hline 11 & Benzyle ester of benzoic ACl C 14 H12 O2 \\
\hline 12 & Heneicosane,3-methyle (Docosane) C22 H46 \\
\hline
\end{tabular}

Antimicrobial Properties

Rissoides desmaresti shell extract \& antimicrobial activity:

The difference between the groups treated with shell extract $(1.5,2.5$, and $5 \mathrm{mg} / \mathrm{mL})$ and the control group was significant, as shown in table (6). The results demonstrated that this Rissoides desmaresti extract has a significant antibacterial activity against the germs Staphylococcus aureus. When it comes to Bacillus subtilis, Klebsiella pneumoniae, and Micrococcus latus, it has a mild impact. Simultaneously, the extract had a little impact on Escherichia coli, Pseudomonas aeruginosa, Bacillus pumilus and Candidal albicans. In addition, it has a minor effect on Aspergillus valves fungus and has no effect on Aspergillus niger. 
Table (6): Antimicrobial activity of Rissoides desmaresti shell extract

\begin{tabular}{|l|c|c|c|}
\hline \multicolumn{1}{|c|}{ Samples Test } & \multicolumn{3}{c|}{ Concentrations (mg/ml) } \\
\cline { 2 - 4 } & 1 & 2.5 & 5 \\
\hline Escherichia coli & + & + & + \\
\hline Bacillus subtilis & ++ & ++ & ++ \\
\hline Klebsilla pneumonia & ++ & ++ & ++ \\
\hline Pseudomonas aeruginosa & + & + & + \\
\hline Staphylococcus aureus & +++ & +++ & +++ \\
\hline Bacillus pumilus & + & + & + \\
\hline Micrococcus luteus & ++ & ++ & ++ \\
\hline Candidal albicans & + & + & + \\
\hline Aspergillus niger & - & - & + \\
\hline Aspergillus valvus & + & + & + \\
\hline
\end{tabular}

The effect of Rissoides desmaresti shell extract on (Hep 2) cell line (Microscopic examination):

The effect of Rissoides desmaresti shell extract on larynx cancer cell line (Hep 2) through culture assay (Table 7) indicated a significant difference between the groups treated with shell extract $(20,40,80$, and $160,320 \mu \mathrm{g} / \mathrm{mL})$ compared to the control group. The results revealed that the effect of Rissoides desmaresti shell extract was clear especially with dilution 20, while with dilution 40 and dilution 8, the effect of Rissoides desmaresti shell extract was weak. In spite of the above mentioned results, the Rissoides desmaresti shell extract did not affect (Hep 2) cancer larynx cell line through culture assay with another dilution specially with 160 and 320 dilutions, (Table $7 \&$ figure 1 ).

Table (7): The effect of Rissoides desmaresti shell extract on (Hep 2) cell line (Microscopic examination)

\begin{tabular}{|l|c||c||c|c|c|}
\hline Dilution & $\mathbf{2 0}$ & $\mathbf{4 0}$ & $\mathbf{8 0}$ & $\mathbf{1 6 0}$ & $\mathbf{3 2 0}$ \\
\hline \hline $\begin{array}{l}\text { The effect of Rissiodes desmaristi shell extract } \\
\text { on (Hep 2) cell line microscopic examination }\end{array}$ & +++ & + & + & - & - \\
\hline
\end{tabular}

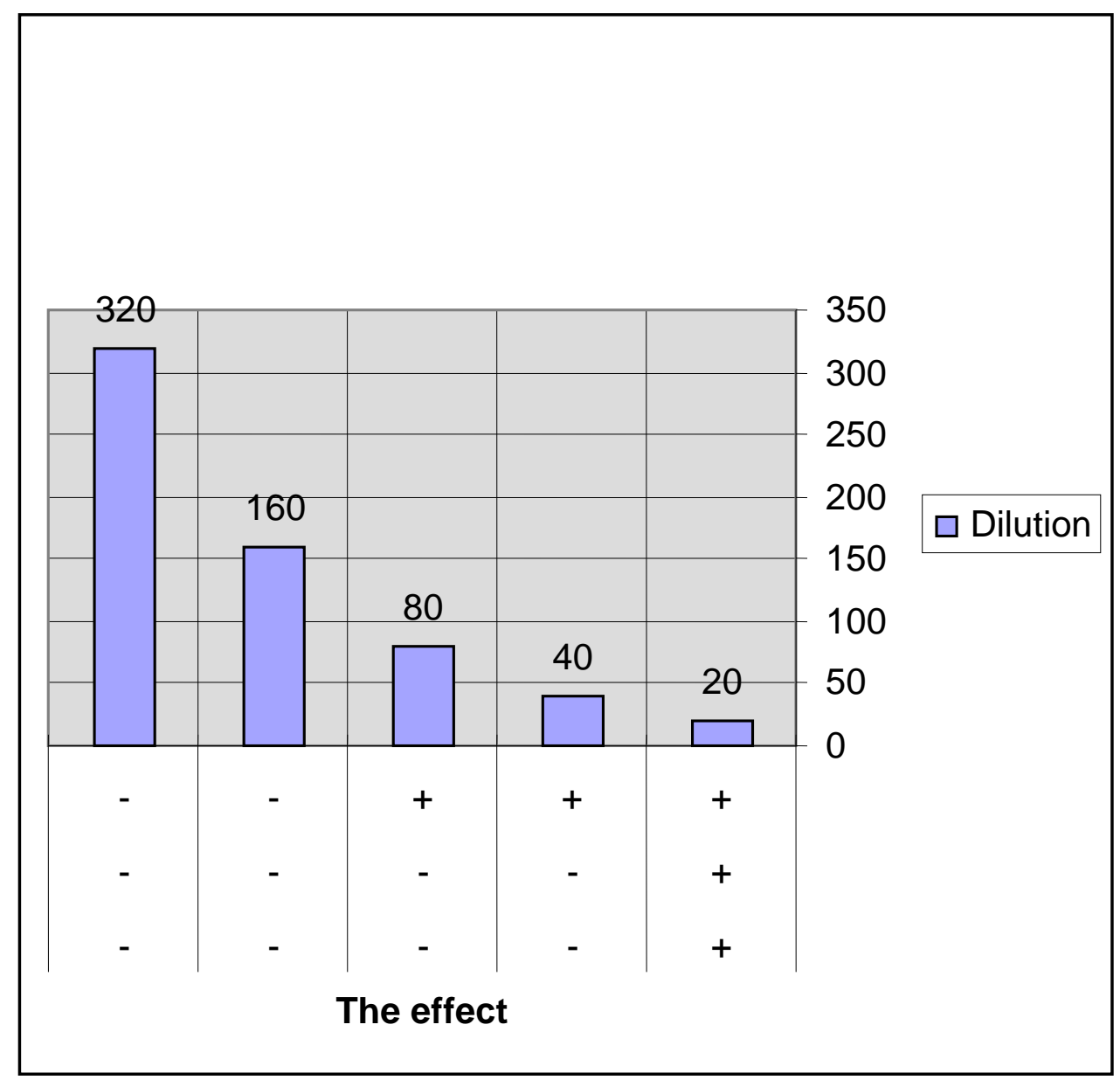

Figure (1): The effect of biological extract of Rissoides desmaresti on (Hep 2) cell line (Microscopic examination). 
Tissue culture toxic dose $50 \mathrm{mg}$ (The concentration of inhibition or toxicity)

The result revealed that toxicity of biological extracts using cell culture assay revealed that the effect of Rissoides desmaresti shell crude extract showed toxic (or inhibitory) effect on larynx cancer cell line (Hep 2). The toxic concentration for larynx cancer cell line (Hep 2) was $1.82 \mathrm{mg}$ through the shell crude extract of Rissoides desmaresti.

Evaluation of viability \% of Hep -2 cell line posttreatment with studied Crustacean extracts using Sufranin uptake assay as (M T T) uptake:

The effect of biological extracts on larynx cancer cell line (Hep 2) through culture assay (by the viability of cell) indicated a significant difference between the groups treated with shell extract $(20,40,60,80$, $160,320,640,1280$ and $2560 \mu \mathrm{g} / \mathrm{mL}$ ) compared to the control group (Table $8 \&$ figure 2 ).
Table (8): Evaluation of viability \% of Hep -2 cell line post treatment with Rissoides desmaresti crud shell extract using cell viability:

\begin{tabular}{|c|c|}
\hline $\begin{array}{c}\text { Dilution of } \\
\text { Rissiodes desmaristi } \\
\text { shell extract }\end{array}$ & $\begin{array}{c}\text { viability \% of } \\
\text { Hep -2 cell }\end{array}$ \\
\hline $\mathbf{1 / 2 0}$ & 51.8 \\
\hline $\mathbf{1 / 4 0 .}$ & 78.6 \\
\hline $\mathbf{1 / 8 0}$ & 88.6 \\
\hline $\mathbf{1 / 1 6 0}$ & 88.7 \\
\hline $\mathbf{1 / 3 2 0}$ & 88.6 \\
\hline $\mathbf{1 / 6 4 0}$ & 100 \\
\hline $\mathbf{1 / 1 2 8 0}$ & 100 \\
\hline $\mathbf{1 / 2 5 6 0 .}$ & 100 \\
\hline
\end{tabular}

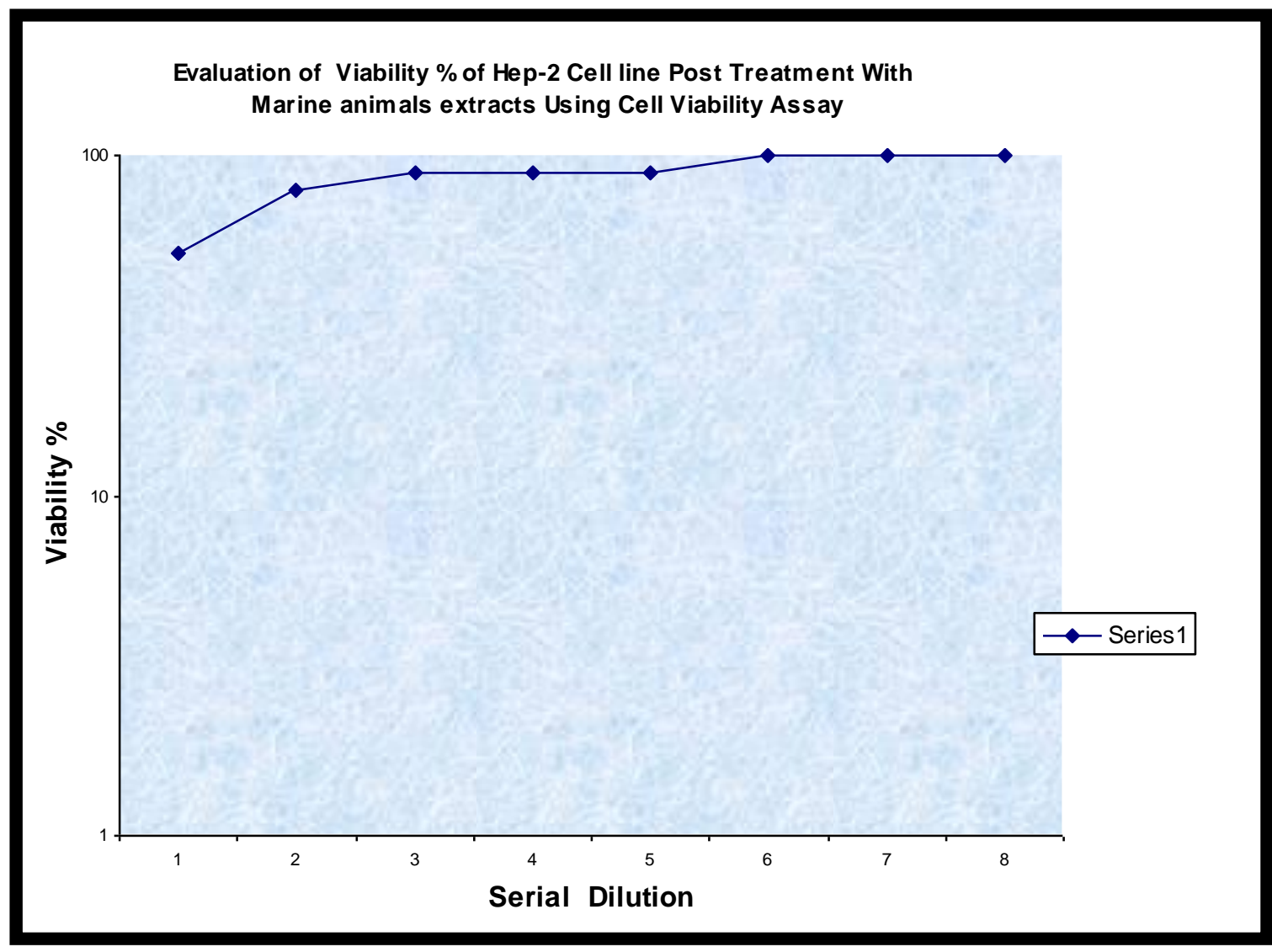

Figure (2): Evaluation of viability \% of Hep -2 cell line post treatment with Crustacean extracts using cell viability Assay.

The evaluation revealed that the effect of Rissoides desmaresti shell extract was clear specially with dilution 20. While, with dilution 40 and dilution 80 the effect of Rissoides desmaresti shell extract were weak. In the same time, the Rissoides desmaresti shell extract did not affect Hep 2 cancer larynx cell line through culture assay with another dilution specially with 160 and 320 dilutions, through culture assay. Meaning that cell viability decreased depending on dose or concentration, (Figures 3, 4, 5 and 6). 
Figure (3): Control of larynx cancer (Hep -2 cell line).

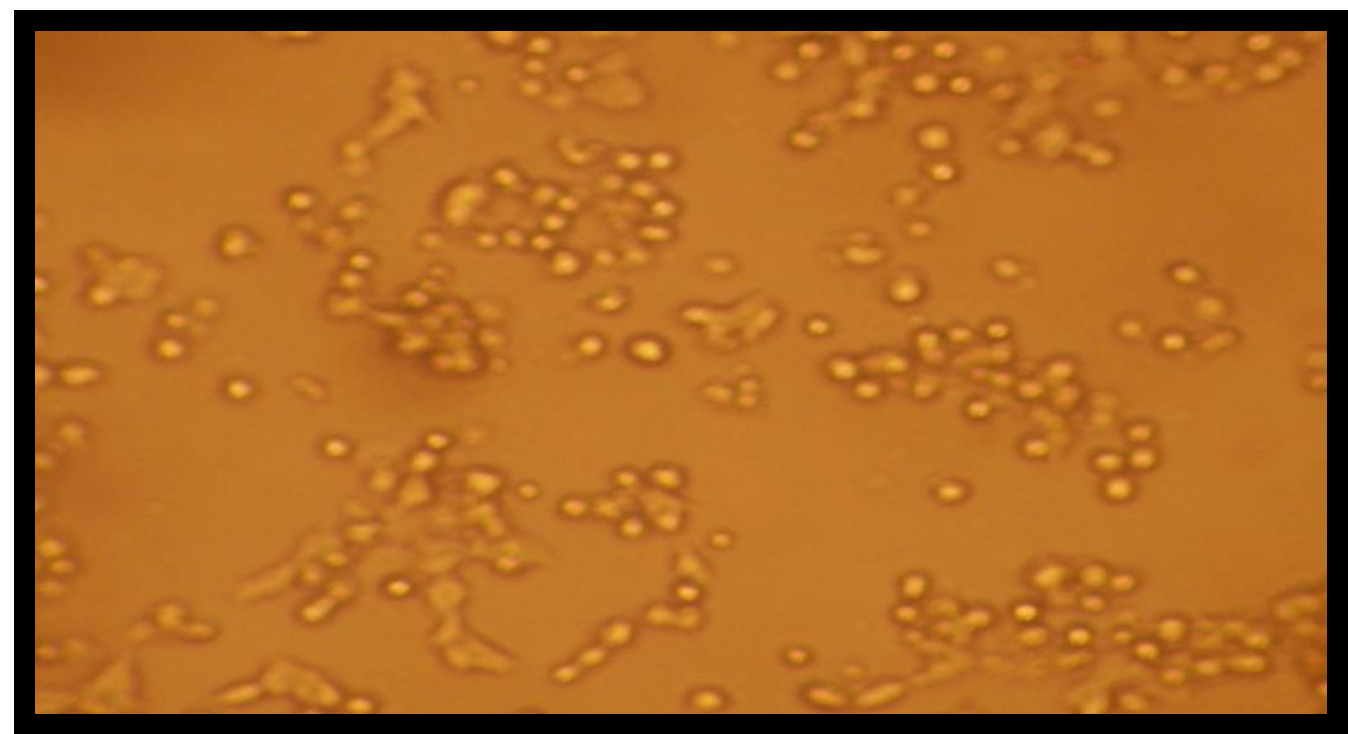

Figure (4): The effect of Rissoides desmaresti shell extract (dilution 20) on larynx cancer cell line.

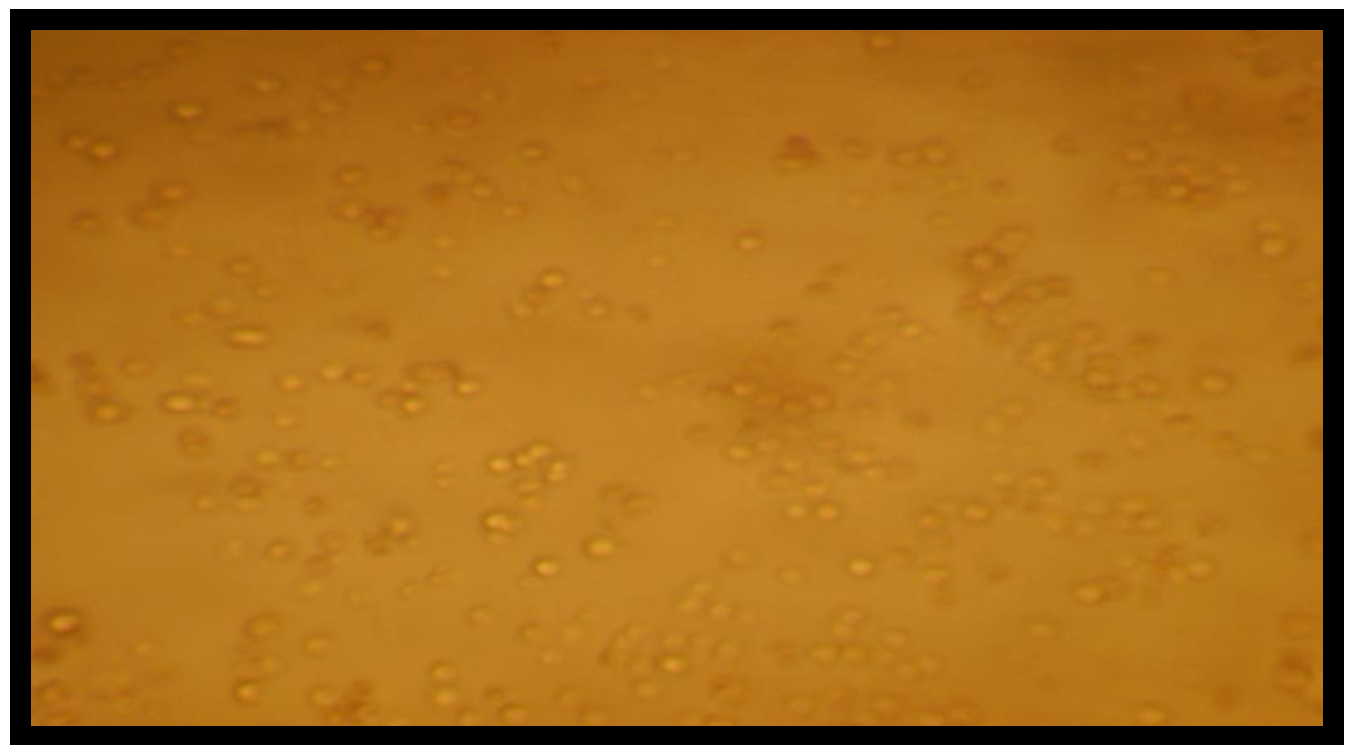

Figure (5): The effect of Rissoides desmaresti shell extract (dilution 40) on larynx cancer cell line. 


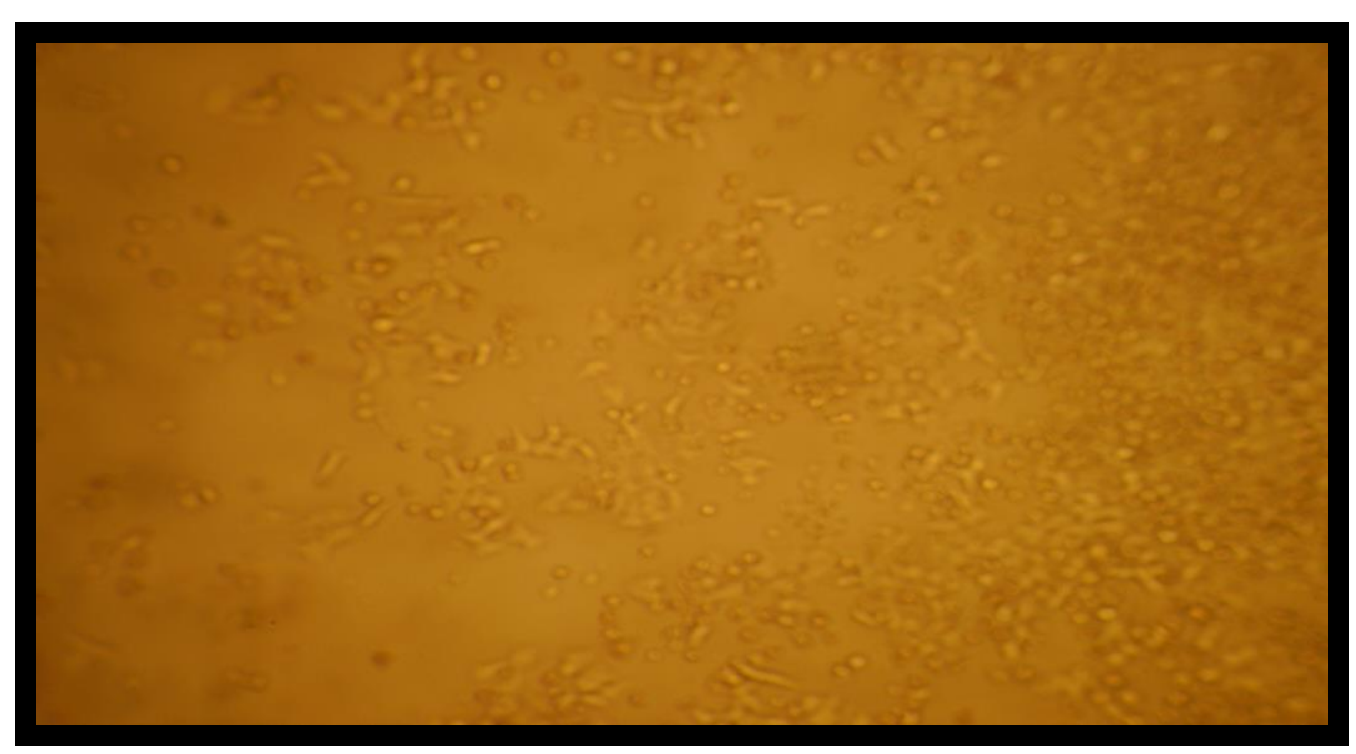

Figure (6): The effect of Rissoides desmaresti shell extract (dilution 80) on larynx cancer cell line.

\section{DISCUSSION}

One of the main goals of the ecologists is to identify factors, which influence of organisms. This goal is difficult to achieve due to the complexity of natural marine environment ${ }^{(22)}$.

The knowledge about Rissoides desmaresti (Stomatopoda-Squillidae) is very important. This animal plays an important role in the food chain, food web, marine ecosystem, as well as, the diet and health of the population. There is alteration in environmental condition of sea that influences all physical, chemical and biological processes ${ }^{(3)}$.

Benedetta and Paul ${ }^{(22)}$ emphasized that there are shortage to complement scientific knowledge about mantis shrimp (Squilla mantis).

Abd-Elaziz (5) stated that the seasonal variation lead to alteration of the environmental factors in marine habitats, which affect biochemical composition of marine animals. Regarding seasons, the fluctuations in the crustaceans might relate not only to water temperature but also to its indirect influences on their food items. It was noticed that, the proximate composition in the studied species was changed from season to another. This agrees with Farina et al. ${ }^{(23)}$ who reported that the feeding of some species can exert strong effects on ecosystem process.

The current study showed that there was a differentiation in the environment surrounding Rissoides desmaresti through monitoring the change in the percentages of the presence of marine algae as one of the important food and environment elements, which varied from one season to another. In general, the results showed a seasonal variation in presence of marine algae from the major divisions: Rhodophyceae (red algae), Phaeophyceae (brown algae) and Ulvophyceae (green algae) where the observed species number differed from one season to another in the environment. The highest number was recorded in spring, while the lowest was recorded in winter. On the other hand, the numbers of species in the summer was higher than in autumn with annual total number of 25, 18 and 18 for Rhodophyceae, Phaeophyceae and Ulvophyceae respectively. While, the total number of species was 61 . The results showed a clear seasonal variation in the percentage of marine algae that was reflected on the number of species recorded for each season, and therefore on the total number of species observed in the environment of the organism under study did not hide the extent to which this is related to productivity, growth, food availability and environmental yield. This is in line with the findings of, Naczk et al. ${ }^{(24)}$ and Nasef ${ }^{(12)}$, who noted changes in biodiversity, diet nutritional composition (25), surrounding medium (26) and other environmental parameters linked with seasonal variance ${ }^{(7)}$. Because the elements are many and overlap, this study attempted to determine the magnitude of their influence and which are more significant ${ }^{(27)}$. Velasco et al. (6) emphasised that there are changes in environmental factors associated with global change at the organism level. The findings obtained in this study are similar to those obtained previously, and confirm the findings regarding different ecological factors, seasonal variation, and its impact on organisms, food cycle, and marine ecosystem ${ }^{(5)}$. The photosynthetic activity of aquatic flora, temperature, salinity, and the quantity of organic components all have a significant impact ${ }^{(4,5)}$.

Shrimp make up a significant part of the processed seafood sector. The exoskeleton (shell) and cephalothorax, which make up roughly $30-40 \%$ of the raw shrimp weight, are thrown as garbage. 
Approximately $60 \%$ of cancer medications authorised by the FDA are derived from natural sources (28). Munro et al. ${ }^{(29)}$ published an earlier review of antitumor and cytotoxic compounds from marine organisms in 1987, which covered the literature until early 1986 . The main goal was to include all natural marine products as well as antimicrobials.

Tor Haug et al. (30) investigated antibacterial activity in four marine crustacean decapods and documented antibacterial activity in several shrimp and crab body sections. Crude extract from the shell of Squilla mantis gives good impact on microbiological species (Bacteria and Fungi) e.g. Bacillus subtilis, Pseudomonas aeruginosa, staphylococcus aureus, B.p, Candida, and produce mixed results with others, according to the first record via the current investigation. Thirunavukkarasu et al. (31) investigated the synthesis of chitin in two marine stomatopods, claiming that just a few studies on crustacean stomatopods relevant to chitin extraction are accessible. Chitin was isolated from marine crustacean shell waste by Mohan et al. ${ }^{(32)}$ (shrimp, crab, squilla and lobster). According to El-Mehdawy et al. ${ }^{(33)}$, shrimp shell extract (Penaeus semisulcatus) has a significant amount of chitosan and chitin, both of which inhibit microorganisms (-ve gram). Nasef (25) found that shrimp shell extract includes a high concentration of chemical substances that inhibit bacteria (-ve and +ve Gram) and fungus. This conclusion is supported by the findings of the current research.

Crude extract on the other hand, was found to have a positive effect on the Hep II cell line (Cancer larynx) in the current study, especially at high concentrations. Crab shell extract suppressed the growth of breast cancer cell line in a dosage and timedependent manner, according to Leila et al. ${ }^{(34)}$.

The results of this study are comparable with those previously acquired, and they support the findings about several cancer cell lines that were generated in partnership with marine biologists and ecologists as an important element of marine natural products chemists' research. Although, the results of this study provide detailed information about the biochemical composition of Rissoides desmaresti, the most common marine benthic crustacean in the Mediterranean Sea. They also reflect the impact of environmental factors on the biochemical composition of one marine benthic crustacean, which calls for more research and studies.

Finally, we need additional research on the effects of the environment on crustaceans utilising single and double variable trials. These experiments are usually carried out to gain a better understanding of biological processes. It is time to take a more comprehensive approach to investigate environmental variability and climate change, as well as their consequences, by combining large-scale, long-term information with large-scale oceanographic and biophysical models to develop an intelligible and employable hypothesis.

\section{CONCLUSION}

The current study revealed that there is a need to shed more light on marine organisms (plant and animal) and the environmental interrelationships between them, and the extent of their impact on marine productivity, food availability and the environment, and their biological, formative and environmental impacts on organisms and the ecosystem.

\section{REFERENCES}

1. Whiteley $\mathbf{N}$ (2011): Physiological and ecological responses ofcrustaceans to ocean acidification. MARINE ECOLOGY PROGRESS SERIESMar Ecol Prog Ser., 430: 257-271.

2. Akram U M, Mohammad I, Towhid H, Marjia S, Nurul H, Robiul H (2020): Biochemical composition and caloric values of different body segments of the female mangrove crab (Scylla olivacea). Egyptian Journal of Aquatic Biology \& Fisheries, 24(7): 817 - 823.

3. Bridget S, Caleb G, Jennifer D, Adrian L (2014): Environmental effects on fished lobsters and crabs. Rev Fish Biol Fisheries, 24: 613-638

4. Hutchinson $G$ (1957): A treatise on limnology (Geography, Physics and Chemistry). John Wiley \& Sons. Inc. New York, vol. 1, Pp: 1015.

5. Abd-Elaziz A (2009): Biological studies on some benthic crustaceans from Abu-Qir Bay (Alexanria - Egypt). Ph.D Sc. Thesis in Marine Ecology, Faculty of Science. Al-Azhar University. Pp: 316.

6. Velasco J, Gutie' rrez C, Botella-Cruz M et al. (2019): Effects of salinity changes on aquaticorganisms in a multiple stressor context.Phil. ttp://dx.doi.org/10.1098/rstb.2018.0011

7. Co^te'I, Darling E, Brown C (2016): Interactionsamong ecosystem stressors and their importance in conservation. doi:10.1098/rspb.2015.2592

8. Scha fer R, Piggott J (2018): Advancingunderstanding and prediction in multiple stressorresearch through a mechanistic basis for nullmodels. Glob. Chang. Biol., 24: 1817-1826.

9. Trang, Phuong P (2012): Bioactive Compounds from By-Products of Shrimp Processing Industry in Vietnam. Journal of Food and Drug Analysis, 20 (1): 194-197.

10. Abouzeed A, Omayma E, Ibrahim S, Attia R, Aboulyazeed A (2015): Production and Evaluation of Some Bioactive Compounds Extracted from Squilla (Oratosquilla massavensis) Shells. American Journal of Life Sciences, 3 (6-1): 38-44.

11. Benedetta V, Paul G (2021): Fishers' knowledge detects ecological decay in the MediterraneanSea. Ambio., 50: 1159-1171

12. Nasef A (2016): Seasonal Variation of Biochemical Composition of Penaeus Semisulcatus (Decapoda: Penaeidae) and the Effect of Its Shell Extract on Bacteria, Fungi and Cancer. The Egyptian Journal of Hospital Medicine, 65: 598- 610.

13. Morsy G, Bekhet E, Mohamed A (2020): Phytochemical screening for antibacterial compounds of 
some seaweed from coastal area of abu-qir , alexandria , egypt phytochemical screening for antibacterial compounds of some seaweed from coastal area of abuqir , alexandria. Egyptian J. of Phycol., 19: 47-57.

14. Ganesan A R, Tiwari U, Rajauria G (2019): Seaweed nutraceuticals and their therapeutic role in disease prevention. Food Sci. Hum. Wellness 8: 252-263. https://doi.org/10.1016/j.fshw. 2019.08.001.

15. FAO (1973): FAO species identification sheets for fishery purposes. Mediterranean and black Sea (fishing areas 37). https://agris.fao.org.

16. Riedel R (1970): Fauna and flora der Adria Hamburg: Parey, Pp: 702.

17. Campbell A (1982): The flora and fauna of the Mediterranean Sea, The Hamlyn puplishing group limited, London, Pp: 320.

18. Aleem A (1993): Marine algae of Alexandria, Ed. University of Alexandria Egypt, Pp.:154.

19. Masada Y (1976): Analysis of essential oil by Gas Chromatography and Mass Spectrometry.John Wiley \& Sons, Inc. https://lib.ugent.be/catalog.

21. Senthilraja $\mathbf{P}$, Kandasamy $\mathbf{K}$ (2015): In vitro cytotoxicity MTT assay in Vero, HepG2 and MCF -7 cell lines study of Marine Yeast. Journal of Applied Pharmaceutical Science, 5(3):080-084.

22. Lee S ( 2008): Mangrove macrobenthos: Assemblages, services, and linkages. Journal of Sea Research, 59 (1-2): 16-29.

23. Farina J, Castilla J , Ojeda F (2003) : The "idiosyncratic effect of a "sentinet' species on contaminated rocky intertidal communities. Scalagical Applications, 3 (6): 1533 - 1552.

24. Naczk M,Williams $J$, Brennan $K$ et al. (2004): Compositional characteristics of green crab (Carcinus maenas). Food Chem., 88: 429-434.

25. Fabris G, Turoczy N, Staginitti F (2006) : Trace metal concentrations in edible tissue of snapper, flathead, lobster, and abalone from coastal waters of Victoria, Australia. Ecotox. Environ. Safe, 63: 286-292.

26. Kádár E, Costa V, Santos $R$ (2006): Distribution of micro-essential $(\mathrm{Fe}, \mathrm{Cu}, \mathrm{Zn})$ and toxic metals in tissues of two nutritionally distinct hydrothermal shrimps. Sci. Total Environ., 358: 143-150.

27. Vicenç M, Miquel P, Andrés O, Sílvia P, Amina B, Mark G, Beatriz M, Francisco A, Ignacio A (2021): Projected effects of ocean warming on an iconic pelagic fish and its fishery. Scientific Reports, 11: 8803.

28. Soundarapandian $P$, Ravichandran $S$, Varadharajan D (2013): Biochemical Compostion of Edible Crab, Podophthalmus Vigil (Fabricius). J. Marine Sci Res Dev. 2:3.

29. Munro M, Luibrand R, Plunt G (1987): The search for antiviral and anticancer compoundes from marine organisms, in Bioorganic Marine Chemistry. V. 1(P.J.Scheuer, ed)., Springer-Verlage, new york, Pp: 93 176.

30. Tor Haug A, Kjuul K, Erling S et al. (2002): Antibacterial activity in four marine crustacean decapods. Institute of Marine Biotechnology, The Norwegian College of Fishery Science, University of Troms $\varnothing$ Breivika, N-9037, Troms $\emptyset$, Norway ${ }^{\mathrm{b}}$ Norwegian Institute of Fisheries and Aquaculture N-9291, Troms $\varnothing$, Norway. https://pubmed.ncbi.nlm.nih.gov.

31. Thirunavukkarasu N, Dhinamala R , Moses I (2011): Production of chitin from two marine stomatopods Oratosquilla spp. (Crustacea). J. Chem. Pharm. Res., 3 (1): 353-359.

32. Mohan K, Muralisankar T, Jayakumar $\mathbf{R}$, Rajeevgandhi C (2021): A study on structural comparisons of $\alpha$-chitin extracted from marine crustacean shell waste. https://doi.org/10.1016/j.carpta.2021.100037

33. El-Mehdawy A, Abd El-Aziz A, Abo Seena F et al. (2015): Study of some rotistes using nano-techinques. M.Sc thesis, zoology Dep., Faculty of Science Al-Azhar University, Cairo, Egypt, Pp:179.

34. Leila R, Zahra R, Pegah M,et al. (2014): Antiproliferatory Effects of Crab Shell Extract on Breast Cancer Cell Line (MCF7). J Breast Cancer, 17 (3): 219225. 